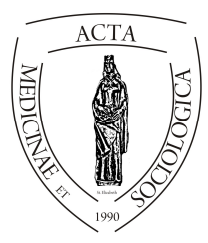

\title{
A „Nyíregyháza Életminősége 2018” vizsgálat és a kutatás módszertana
}

\author{
Huszti Éva ${ }^{1}$, Hüse Lajos ${ }^{2}$, Takács Péter ${ }^{3}$, Fábián Gergely ${ }^{4}$ \\ ${ }^{1}$ főiskolai docens, Debreceni Egyetem Egészségügyi Kar, 4400 Nyíregyháza, Sóstói út 2-4. \\ ${ }^{2}$ föiskolai docens, Debreceni Egyetem Egészségügyi Kar. 4400 Nyíregyháza, Sóstói u. 2-4. \\ ${ }^{3}$ főiskolai tanár, Debreceni Egyetem Egészségügyi Kar, 4400 Nyíregyháza, Sóstói út 2-4. \\ ${ }^{4}$ főiskolai tanár, Debreceni Egyetem Egészségügyi Kar, 4400 Nyíregyháza, Sóstói u. 2-4
}

\begin{tabular}{|c|c|}
\hline INFO & ABSTRACT \\
\hline $\begin{array}{l}\text { Keywords } \\
\text { Nyíregyháza, household } \\
\text { panel survey, quality of } \\
\text { life studies, }\end{array}$ & $\begin{array}{l}\text { Survey features of the Quality of Life Research Series } \\
\text { in Nyíregyháza, Fifth Wave. The Nyíregyháza Quality of } \\
\text { Life Research started ten years ago. The fifth wave of this } \\
\text { research occurred in } 2018 \text {. This essay introduces the } \\
\text { sampling details of the research to the readers. }\end{array}$ \\
\hline $\begin{array}{l}\text { Kulcsszavak } \\
\text { Nyíregyháza, panelfel- } \\
\text { mérés, életminőség vizs- } \\
\text { gálatok, mintavétel }\end{array}$ & $\begin{array}{l}\text { Absztrakt. A tíz éve indult Nyíregyháza Életminőségi } \\
\text { kutatássorozat ötödik felmérési hulláma 2018-ban zajlott. } \\
\text { Az írás a vizsgálat mintavételi részleteit tárja az olvasók } \\
\text { elé. Elsőként közvetlenül az adatfelvétellel kapcsolatos } \\
\text { elökészítő lépések kerülnek bemutatásra. Ezután a mérési } \\
\text { anomáliákról és azok kezeléséről, majd az adatrögzítésröl, } \\
\text { az adatok tisztításáról és súlyozásáról lesz szó. Ebben a } \\
\text { hullámban az egészségi állapot felmérése különállóan tör- } \\
\text { tént - ennek részletei követik az előzőeket. Az írás máso- } \\
\text { dik fele az ötödik hullám alapadatait a korábbi felmérések- } \\
\text { hez hasonlítja. Ez a rész eleveníti fel a kutatássorozat gyö- } \\
\text { kereit, a korábbi eredmények ide tartozó - a mintavétellel } \\
\text { kapcsolatot - egyes részleteit. }\end{array}$ \\
\hline
\end{tabular}

Ez a tanulmány a Nyíregyháza város életminősége - Háztartáspanel kutatás Egészségi állapot felmérése keretében készült. 


\section{Bevezetés}

A Nyíregyháza Életminősége panelvizsgálat tíz éve, 2008-ban indult. A kutatássorozat keretében két, majd háromévente került sor az újabb adatfelvételekre. Az eddigi adatfelvétel évei 2008, 2010, 2012, 2015 és 2018 voltak. A felmérések célja a nyíregyházi felnőtt népesség életkörülményeinek, élet-összetevőinek, életminőségének vizsgálata; a jellegzetességek feltárása és a változások nyomon követése. A kutatás időről időre képet adott/ad a város felnőtt lakosságának helyzetéről, a városi élet minőségröl. Az eredmények többek között hozzájárultak a különböző témájú településfejlesztési célok tervezéshez és eléréséhez, az önkormányzati feladatok megalapozott ellátásához.

Az eddigi kutatási eredményekről tudományos publikációk is beszámoltak, melyek legjelentősebb kiadványai az Életminőség Nyíregyházán 2008-2010 (2012), az Életminöség Nyíregyházán 2012 (2014), a Nyíregyházi járás életminősége 2015 (2015) tanulmánykötetek.

Jelen írás fó célja az ötödik, 2018-ban lezárult mintavétel jellemzőinek összefoglalása. Elsőként közvetlenül az adatfelvétellel kapcsolatos elökészítő lépések kerülnek bemutatásra. Ezután a mérési anomáliákról és azok kezeléséről, majd az adatrögzítésről, az adatok tisztításáról és súlyozásáról lesz szó. Ebben a hullámban az egészségi állapot felmérése különállóan történt - ennek részletei követik az elözőeket. Az írás második fele az ötödik hullám alapadatait a korábbi felmérésekhez hasonlítja. Ez a rész eleveníti fel a kutatássorozat gyökereit, a korábbi eredmények ide tartozó a mintavétellel kapcsolatot - egyes részleteit.

\section{Az ötödik hullám - 2018}

Felkészülés - kérdőív előkészítése, címlista, sokszorosítás, kérdezőbiztosok felkészítése. Az ötödik hullám előkészítő fázisai már 2017 szeptemberében elkezdődtek. Mint minden előző felmérés (adatfelvételi „hullám”) esetében, itt is először a korábbi kérdőívek kérdésblokkjainak, kérdéseinek áttekintésére, aktualitásának vizsgálatára volt szükség. Ezen munka eredményeképp született meg az a döntés, hogy - az Egészségügyi Kar profilját hangsúlyozandó, illetve a városi fejlesztési tervekhez igazodva - különálló részbe kerüljenek a városlakók egészségi állapotára, egészségtudatosságára, az egészségügyi ellátórendszer használatára vonatkozó kérdések. Az alapkérdőívben csak az önálló elemzésekhez szükséges egészségi állapotra vonatkozó kérdések maradtak.

Az elkészült mintakérdőívet a témagazdák (a szükebb tématerületek szakemberei) elektronikus levélben kapták kézhez, és jelezhették javaslataikat a kérdőív szerkesztői felé.

Mindeközben megkezdődött a címlista összeállítása, frissítése is. A kutatás céljához igazodva legtágabb mintavételi keretként a felmérés időpontjában tizennyolcadik életévüket betöltött nyíregyházi lakosok összessége tekinthetö. Az ötödik hullámban is a Közigazgatási és Elektronikus Közszolgáltatások Központi Hivatala 
által szolgáltatott (2015-ben) címek kerültek felhasználásra - fócímlista: 1000 háztartás; 500 pótcím.

A háztartások - mint előzőleg is mindig - levélben kaptak tájékoztatást a kérdezés tényéről és várható időpontjáról. A város polgármestere és a kutatásvezető által aláírt levél pontos és részletes tájékoztatást nyújtott a kutatás témájáról, céljairól és biztosította a válaszadókat az alapvető kutatásetikai szabályok (anonimitás, önkétes válaszadás, stb.) betartásáról.

A kérdöívek sokszorosításával párhuzamosan történt a kérdezőbiztosok felkészítése. A kérdezők az Egészségügyi Kar hallgatói voltak, akik kutatásmódszertani tanulmányaik gyakorlati alkalmazásaként, külön kurzusra jelentkezve vehettek részt a kutatómunkában. Ez az előkészítő és oktatási fázis részletesen áttekintette az alkalmazásra kerülő kérdőív kérdéseit, a folyamat lebonyolítását, annak etikai és módszertani szabályait. A kérdezőbiztosok a kutatás időtartamára vonatkozóan megbízólevelet kaptak.

Mintavétel lefolytatása, válaszmegtagadások. A tényleges és teljes adatfelvétel 2017 októberétől 2018 május közepéig tartott. Ennek során a kérdezőbiztosok a kézhez kapott címlista címeit próbálták meg elérni; a lekérdezést végrehajtani. Egyegy kérdezőbiztosra átlagosan 10 cím jutott. Az adatfelvétel során az ötödik hullámban, a korábbi évekhez viszonyítva, a lekérdezők sokkal nagyobb válaszmegtagadással szembesültek. Az eredeti címeken a feldolgozásra került kérdöívek 55\%-a készült.

A kérdőívek adatainak rögzítése, adattisztítás. Az Egészségügyi Karra visszakerült kérdőívekkel szintén a kar hallgatói dolgoztak tovább. A sorszámmal ellátott, már anonimizált lapokon lévő adattartalmat a kidolgozott kódolási utasítás szerint először Excel táblázatba rögzítették az adatfelvivők. A különálló Excel állományok ellenőrzés után kerültek összefésülésre, majd az adatok transzformációjára került sor - ami az SPSS statisztikai programcsomagja által betölthető formátum kialakítását és a feldolgozást könnyítő címkézést jelentette.

Adattisztítás, súlyozás. Az adattisztítás eredményeként a feldolgozott 541 kérdőívből elöször 504, majd az ismételt ellenőrzés után kereken 500 ténylegesen használható maradt az adatbázisban. A válaszmegtagadások nagy száma okán már sejteni lehetett, hogy a korábbi felmérések egyszerübbnek tekinthető, nemekre vonatkozó súlyozásán kívül szükség lesz több változó bevonására is az adatok súlyozásához. Az első leíró statisztikai eredmények igazolták a sejtést. A nem, a kor és az iskolai végzettség szerinti megoszlások eltérését 2011-es népszámlálási eredményektől az 1. táblázat mutatja be. Kiemelhető például a táblázatból, hogy a teljes mintában felülreprezentáltak a közép- és felsőfokú végzettségüek és alulreprezentált az ennél alacsonyabb iskolai végzettség. A férfiaknál az érettségizettek aránya kiemelkedő a mintában, a nők esetében a felső három iskolakategória magasabb. 


\begin{tabular}{|c|c|c|c|c|c|c|}
\hline $\begin{array}{c}\text { Népszám- } \\
\text { lálás } \\
\text { férfiak \% }\end{array}$ & $\begin{array}{c}1 \\
<8 \text { általá- } \\
\text { nos }\end{array}$ & $\begin{array}{c}2 \\
8 \text { általá- } \\
\text { nos }\end{array}$ & $\begin{array}{c}3 \\
\text { szakiskola } \\
\text { érettségi nélkül }\end{array}$ & $\begin{array}{c}4 \\
\text { érettségi }\end{array}$ & $\begin{array}{c}5 \\
\text { felsőfok }\end{array}$ & Összes \\
\hline $120-29$ & 0,07 & 0,79 & 1,43 & 4,22 & 1,43 & 7,94 \\
\hline $230-39$ & 0,09 & 0,96 & 3,68 & 3,15 & 3,09 & 10,98 \\
\hline $340-49$ & 0,06 & 0,80 & 3,06 & 2,29 & 1,93 & 8,14 \\
\hline $450-59$ & 0,06 & 0,87 & 3,20 & 2,23 & 1,80 & 8,17 \\
\hline $560+$ & 0,39 & 2,78 & 1,72 & 2,70 & 2,38 & 9,96 \\
\hline Összes & 0,67 & 6,20 & 13,09 & 14,59 & 10,63 & 45,18 \\
\hline Minta-férfiak \% & 0,50 & & & \\
\hline $120-29$ & 0,00 & 0,22 & 0,90 & 8,76 & 1,80 & 11,69 \\
\hline $230-39$ & 0,00 & 0,00 & 1,80 & 2,92 & 2,02 & 6,74 \\
\hline $340-49$ & 0,00 & 0,22 & 0,45 & 1,80 & 1,80 & 4,27 \\
\hline $450-59$ & 0,00 & 0,45 & 1,57 & 2,47 & 2,70 & 7,19 \\
\hline $560+$ & 0,00 & 1,12 & 2,25 & 4,49 & 2,47 & 10,34 \\
\hline Összes & 0,00 & 2,02 & 6,97 & 20,45 & 10,79 & 40,22 \\
\hline
\end{tabular}

\begin{tabular}{|c|c|c|c|c|c|r|}
\hline $\begin{array}{c}\text { Népszám- } \\
\text { lálás } \\
\text { nők \% }\end{array}$ & $\begin{array}{c}1 \\
<8 \text { általá- } \\
\text { nos }\end{array}$ & $\begin{array}{c}2 \\
8 \text { általá- } \\
\text { nos }\end{array}$ & $\begin{array}{c}3 \\
\text { szakiskola } \\
\text { érettségi nélkül }\end{array}$ & $\begin{array}{c}4 \\
\text { érettségi }\end{array}$ & $\begin{array}{c}5 \\
\text { felsőfok }\end{array}$ & Összes \\
\hline $120-29$ & 0,09 & 0,56 & 0,79 & 4,09 & 2,73 & \multicolumn{1}{c|}{8,27} \\
\hline $230-39$ & 0,14 & 0,78 & 2,13 & 3,68 & 4,74 & 11,46 \\
\hline $340-49$ & 0,10 & 0,88 & 1,76 & 3,29 & 2,89 & \multicolumn{1}{c|}{8,92} \\
\hline $450-59$ & 0,13 & 1,93 & 2,08 & 3,89 & 2,36 & 10,39 \\
\hline $560+$ & 2,03 & 6,03 & 1,01 & 4,62 & 2,09 & 15,77 \\
\hline Összes & 2,49 & 10,19 & 7,78 & 19,57 & 14,80 & 54,82 \\
\hline Minta-nök \% & 0,00 & 0,00 & 1,12 & 7,87 & 2,92 & 11,91 \\
\hline $120-29$ & 0,00 & 0,67 & 1,12 & 2,25 & 4,27 & 8,31 \\
\hline $230-39$ & 0,00 & 0,00 & 1,35 & 6,07 & 3,37 & 10,79 \\
\hline $340-49$ & 0,00 & 0,22 & 1,35 & 2,70 & 3,37 & 7,64 \\
\hline $450-59$ & 0,67 & 3,60 & 4,27 & 6,29 & 6,29 & 21,12 \\
\hline $560+$ & 0,67 & 4,49 & 9,21 & 25,17 & 20,22 & 59,78 \\
\hline Összes & \multicolumn{7}{|l|}{} \\
\hline
\end{tabular}

\begin{tabular}{|c|c|c|c|c|c|c|}
\hline $\begin{array}{c}\text { Népszám- } \\
\text { lálás \% } \\
\text { Teljes }\end{array}$ & $\begin{array}{c}1 \\
<8 \text { általá- } \\
\text { nos }\end{array}$ & $\begin{array}{c}2 \\
8 \text { általá- } \\
\text { nos }\end{array}$ & $\begin{array}{c}3 \\
\text { szakiskola } \\
\text { érettségi nélkül }\end{array}$ & $\begin{array}{c}4 \\
\text { érettségi }\end{array}$ & $\begin{array}{c}5 \\
\text { felsőfok }\end{array}$ & Összes \\
\hline $120-29$ & 0,16 & 1,35 & 2,22 & 8,31 & 4,16 & 16,20 \\
\hline $230-39$ & 0,23 & 1,74 & 5,81 & 6,83 & 7,83 & 22,44 \\
\hline $340-49$ & 0,16 & 1,68 & 4,82 & 5,58 & 4,82 & 17,06 \\
\hline $450-59$ & 0,19 & 2,81 & 5,29 & 6,12 & 4,15 & 18,56 \\
\hline $560+$ & 2,41 & 8,81 & 2,73 & 7,32 & 4,47 & 25,73 \\
\hline Összes & 3,15 & 16,39 & 20,87 & 34,16 & 25,43 & 100,00 \\
\hline
\end{tabular}




\begin{tabular}{|c|c|c|c|c|c|c|}
\hline \multicolumn{1}{|l|}{ Minta - Teljes \% } \\
\hline $120-29$ & 0,00 & 0,22 & 2,02 & 16,63 & 4,72 & 23,60 \\
\hline $230-39$ & 0,00 & 0,67 & 2,92 & 5,17 & 6,29 & 15,06 \\
\hline $340-49$ & 0,00 & 0,22 & 1,80 & 7,87 & 5,17 & 15,06 \\
\hline $450-59$ & 0,00 & 0,67 & 2,92 & 5,17 & 6,07 & 14,83 \\
\hline $560+$ & 0,67 & 4,72 & 6,52 & 10,79 & 8,76 & 31,46 \\
\hline Összes & 0,67 & 6,52 & 16,18 & 45,62 & 31,01 & 100,00 \\
\hline
\end{tabular}

Forrás: 2011-es Népszámlálás, Központi Statisztikai Hivatal (www.ksh.hu) 15_3_1_4_3.xls egyedi kérésre összeállitott táblázatos adatállomány.

1. táblázat. A nem, a kor és az iskolai végzettség a 2011-es népszámlálási adatokban és a 2018-as adatfelvételben - Nyíregyháza.

Az adatok további feldolgozásához, a megalapozottabb eredmények eléréséhez, a Nyíregyházára vonatkozó reálisabb kép kialakításához tehát nélkülözhetetlen volt, hogy olyan adatok álljanak rendelkezésre, amelyek valamilyen mértékben kiküszöbölik a válaszmegtagadások okozta torzításokat. Az adatok súlyozása az egyik lehetséges módja annak, hogy a minta összetétele közelíthető legyen az alapsokaság összetételéhez. A 2018-as adatfelvételhez legközelebbi, megfelelő adattartalommal bíró, teljes körü adatfelvétel a 2011-es országos népszámlálás volt Nyíregyháza vonatkozásában. Ezt az adatkört bocsátotta a kutatás rendelkezésére a Központi Statisztikai Hivatal (www.ksh.hu; 15_3_1_4_3.xls egyedi kérésre összeállított táblázatos adatállomány). A lehetséges súlyozási módszerek közül a mátrixsúlyozás használata adta a legkönynyebben elérhető, használható eredményt (Szelényi B., 2003). Ez lényegében a bevont változók (nem, kor/korcsoport, iskolai végzettség) szerint képzett háromdimenziós adattábla mintabeli és alapsokaságbeli arányait veszi alapul. A súlyok meghatározása előtt szükséges volt a változók lehetséges értékkészleteinek összehangolására, átkódolására. Mivel a Nyíregyháza Életminősége és a népszámlálás korcsoportos és iskolai végzettség szerinti kategóriái nem egyeztek meg, közös kategóriarendszer kialakítására volt szükség - lásd 2. táblázat.

\begin{tabular}{|c|c|c|c|c|c|c|c|c|c|c|c|c|c|c|c|c|}
\hline \multicolumn{17}{|c|}{ Korcsoportok-KSH alapkategóriák } \\
\hline $7-9$ & $\begin{array}{l}10- \\
14\end{array}$ & $\begin{array}{c}15- \\
17\end{array}$ & $\begin{array}{c}18- \\
19\end{array}$ & $\begin{array}{c}20- \\
24\end{array}$ & $\begin{array}{c}25- \\
29\end{array}$ & $\begin{array}{c}30- \\
34\end{array}$ & $\begin{array}{c}35- \\
39\end{array}$ & $\begin{array}{c}40- \\
44\end{array}$ & $\begin{array}{c}45- \\
49\end{array}$ & $\begin{array}{c}50- \\
54\end{array}$ & $\begin{array}{c}55- \\
59\end{array}$ & $\begin{array}{c}60- \\
64\end{array}$ & $\begin{array}{c}65- \\
69\end{array}$ & $\begin{array}{c}70- \\
74\end{array}$ & $\begin{array}{c}75- \\
79\end{array}$ & $\begin{array}{c}80- \\
84\end{array}$ \\
\hline \multicolumn{17}{|c|}{ Új, egyeztetett korcsoportok } \\
\hline \multicolumn{4}{|c|}{ - } & \multicolumn{2}{|c|}{$20-29$} & \multicolumn{2}{|c|}{$30-39$} & \multicolumn{2}{|c|}{$40-49$} & \multicolumn{2}{|c|}{$50-59$} & \multicolumn{5}{|c|}{$60+$} \\
\hline
\end{tabular}

Iskolai végzettség - KSH alapkategóriák

\begin{tabular}{|c|c|c|c|c|c|c|c|}
\hline \multirow{3}{*}{$\begin{array}{l}\text { Az általános } \\
\text { iskola első évfo- } \\
\text { lyamát sem } \\
\text { végezte el }\end{array}$} & \multicolumn{4}{|c|}{ Általános iskola } & \multirow{3}{*}{$\begin{array}{l}\text { Középfokú iskola } \\
\text { érettségi nélkül, } \\
\text { szakmai oklevéllel }\end{array}$} & \multirow{3}{*}{ Érettségi } & \multirow{3}{*}{$\begin{array}{c}\text { Egyetem, föis- } \\
\text { kola stb. okle- } \\
\text { véllel }\end{array}$} \\
\hline & $\begin{array}{l}1- \\
3 .\end{array}$ & $\begin{array}{l}4- \\
5 .\end{array}$ & $\begin{array}{l}6- \\
7 .\end{array}$ & 8. & & & \\
\hline & \multicolumn{4}{|c|}{ évfolyam } & & & \\
\hline \multicolumn{8}{|c|}{ Uj, egyeztetett végzettségi csoportok } \\
\hline \multicolumn{4}{|c|}{$<8$ általános } & $\begin{array}{l}8 \text { általá- } \\
\text { nos }\end{array}$ & $\begin{array}{l}\text { Szakiskola érettségi } \\
\text { nélkül }\end{array}$ & Érettségi & Felsőfok \\
\hline
\end{tabular}

2. táblázat. A kor és az iskolai végzettség kategóriáinak összehangolása - változók átkódolása. 
Ellenőrzések és az adatállományok eljuttatása a témafelelősöknek. A súlyok kialakítása és az adatállományba történő rögzítése után a súlyozott mintabeli arányok ellenőrzésére került sor - lásd 3. táblázat. Az utolsó oszlopban lévő eltérések a kerekítésekre vezethetők vissza.

\begin{tabular}{|c|c|c|c|c|c|c|}
\hline Nem & $\begin{array}{c}\text { nem } \\
\text { súlyozás } \\
\text { előtt \% }\end{array}$ & valid \% & $\begin{array}{c}\text { nem } \\
\text { súlyozva } \\
\%\end{array}$ & valid \% & KSH \% & $\begin{array}{c}\text { Eltérés } \\
\%\end{array}$ \\
\hline férfi & 38,2 & 39,9 & 42,5 & 44,4 & 45,2 & 0,8 \\
\hline nö & 57,6 & 60,1 & 53,2 & 55,6 & 54,8 & 0,8 \\
\hline összes & 95,8 & & 95,7 & & & \\
\hline hiányzó & 4,2 & & 4,3 & & & \\
\hline
\end{tabular}

\begin{tabular}{|c|r|r|r|r|r|c|}
\hline Kor & $\begin{array}{c}\text { kor } \\
\text { súlyozás } \\
\text { előtt } \%\end{array}$ & valid \% & $\begin{array}{c}\text { kor } \\
\text { súlyozva } \\
\%\end{array}$ & valid \% & KSH \% & $\begin{array}{c}\text { Eltérés } \\
\%\end{array}$ \\
\hline $20-29$ & 22,6 & 23,6 & 15,9 & 16,6 & 16,2 & 0,4 \\
\hline $30-39$ & 14,6 & 15,3 & 20,8 & 21,8 & 22,4 & 0,6 \\
\hline $40-49$ & 14,6 & 15,3 & 16,0 & 16,7 & 17,1 & 0,4 \\
\hline $50-59$ & 14,0 & 14,6 & 17,7 & 18,6 & 18,6 & 0 \\
\hline $60+$ & 29,8 & 31,2 & 25,1 & 26,3 & 25,7 & 0,6 \\
\hline összes & 95,6 & & 95,5 & & & \\
\hline hiányzó & 4,4 & & 4,5 & & & \\
\hline
\end{tabular}

\begin{tabular}{|c|r|r|r|r|r|c|}
\hline Iskola & $\begin{array}{c}\text { kor } \\
\text { súlyozás } \\
\text { előtt \% }\end{array}$ & valid \% & $\begin{array}{c}\text { kor } \\
\text { súlyozva } \\
\%\end{array}$ & valid \% & KSH \% & $\begin{array}{c}\text { Eltérés } \\
\%\end{array}$ \\
\hline$<8$ általános & 0,6 & 0,6 & 1,9 & 2,0 & 3,2 & 1,2 \\
\hline 8 általános & 6,4 & 6,8 & 13,5 & 14,4 & 16,4 & 2 \\
\hline $\begin{array}{c}\text { szakiskola érett- } \\
\text { ségi nélkül }\end{array}$ & 14,8 & 15,8 & 19,6 & 21,0 & 20,9 & 0,1 \\
\hline érettségi & 42,8 & 45,6 & 33,6 & 35,9 & 34,2 & 1,7 \\
\hline felsőfok & 29,2 & 31,1 & 25,0 & 26,7 & 25,4 & 1,3 \\
\hline összes & 93,8 & & 93,6 & & & \\
\hline hiányzó & 6,2 & & 6,4 & & & \\
\hline
\end{tabular}

3. táblázat. A nem, a kor és az iskolai végzettség kategóriáinak súlyozatlan és súlyozott arányai - eltérések oka: számítások során kerekítések.

A lezárt számítások és az elvégzett ellenőrzések után került a témafelelősökhöz a súlyozott adatállomány a további részterületei számítások elvégzésére.

A városi Egészségpanel felmérés néhány részlete. Mint ahogy a bevezető fejezetekben már olvasható volt, 2018-ban a Háztartáspanel kutatás keretein belül, de attól különállóan valósult meg egy egészségre vonatkozó felmérés a lakosok, háztartások körében. A kérdőív két részletben történő lekérdezését az indokolta, hogy az évek során a vizsgált területek jelentősen kiegészültek; a teljes lekérdezés ideje több órát vett volna igénybe, ami elöre láthatóan nagyobb mértékben vethette volna vissza a 
válaszadási hajlandóságot (ez sajnos a kettéosztással is bekövetkezett). A lakosság egészségi állapotát mérő kérdöív-csomag tehát külön időpontban került felvételre ugyanazon cél-mintán, ugyanazzal a módszertannal. Az ötödik hullám első lekérdezése 2017 őszén, a második pedig 2018 tavaszán indult. Az egészséget mérő kérdőív a korábbiakhoz képest egy új dimenzióval, az egészségmüveltség szintjének meghatározásával bővült. Két validált egészségmüveltséget mérő eszköz került alkalmazásra. Az úgynevezett Chew-kérdéssor attitüd-mérő, előszürési célokra kifejlesztett és alkalmazott kérdéslista (3 item, ötfokú Likert skála). Az értékelés az egyén egészségmüveltségi szintjét három kategóriába sorolja: elégtelen, problémás vagy megfelelő (Papp-Zipernovszky és mtsai., 2016) (Chew LD et al., 2008). A The Newest Vital Sign teszt (6 item, maximálisan 6 pont érhető el) azt méri, hogy az egyén milyen mértékben képes egy termékismertető címkéjén (jégkrém) található információt elolvasva megérteni és a kinyert információt felhasználni - egyszerre három képesség mérése: szövegértés, alapvető számolási készség, problémamegoldó képesség. A pontozás szerinti besorolás: 0-1 pont - nagy valószínüséggel elégtelen, 2-3 pont valószínüsíthetően elégtelen, 4-6 pont megfelelő egészségmüveltséggel kapcsolatos információfeldolgozási szintet jelent (Koltai, Kun, 2016) (Weiss et al., 2005).

Az ötödik hullám első lekérdezése során 541 kitöltött, értékelhető kérdőív érkezett vissza, amely kérdőívekhez tartozó háztartásokat látogattak meg a második lekérdezés során a kérdezőbiztosok. A 2017/2018-as adatfelvétel második lekérdezésbe bekerült 541 háztartásból végül 391 háztartásból érkezett vissza kérdőív, melyből legvégül 386 volt értékelhető (71,35 \%-os válaszadási arány az első lekérdezéshez viszonyítva).

Ehhez, a második lekérdezéshez kapcsolódó elemzésekből csak egyetlen rész került be jelen kiadványba (J. Erdei, Takács, 2018). A továbbiak tervezetten követik majd azon korábbi vizsgálatok célrendszerét és módszertanát, amelyek egyik jelentős összefoglalója Jávorné Erdei Renáta doktori dolgozatában olvasható (Jávorné Erdei R., 2016). Ebben a munkában a városi lakosság egészséggel kapcsolatos visszajelzéseinek elemzésén kívül a városrészek összehasonlító vizsgálatára is sor került. A 2018as felmérés szintén lehetőséget ad hasonló irányú eredmények elérésére.

\section{A 2018-as adatfelvétel a korábbi vizsgálatok tükrében}

A kutatás minden hulláma Nyíregyháza Megyei Jogú Város Polgármesteri Hivatala Szociális és Köznevelési Osztály és a Debreceni Egyetem Egészségügyi Kar együttmüködésében valósult meg. A vizsgálat maga nemzetközi és hazai példákon alapul; a „háztartáspanel” módszertanát követi. Az ilyen eljárások elsődlegesen háztartásokról, másodsorban a háztartás tagjairól gyűjtenek információkat.

A kutatás közvetlen példájának, mintájának az ECHP kutatás (European Community Household Panel - Európai Közösség Háztartáspanel, http1) tekinthető, amely standardizált kérdőívvel, azonos mintán (60.500 európai háztartás, közel 130.000 fö) vizsgálta 1994 és 2001 között az európai polgárok életkörülményeit. Az lekérdezett dimenziókra példák: jövedelmi helyzet, szegénység, gazdasági aktivitás, 
egészségi állapot. Ausztria 1995-ben, Finnország 1996-ban, Svédország pedig 1997ben csatlakozott az adatfelvételekhez. Hazánk ennél később, az ECHP folytatásának tekinthető vizsgálatsorozathoz társult (EU-SILC, Statistics on Income and Living Conditions - Jövedelem és Életminőség Statisztika, http2). A kutatássorozat módosítására azért volt szükség, mert az eredeti mintában szereplö háztartások, személyek közül az idők folyamán sokan „eltüntek” (költözés, elhalálozás, egyéb mobilitás, válaszmegtagadás) a kutatók elől. Ez a jelenség - szakmai néven „panelkopás” már olyan nagymértékủvé vált az ECHP esetén, hogy az reprezentatív adatfelvétel 2001-re gyakorlatilag lehetetlenné vált. A szakmai és politikai körök számára ugyanakkor nyilvánvaló volt, hogy mindenképpen szükséges az ECHP-hez hasonló vizsgálat, hogy rendelkezésre álljanak nemzetközileg is összehasonlítható adatok az egyes tagállamokkal kapcsolatban. Az ECHP-t tehát hivatalosan az EU-SILC követte, melyet 2003-ban hagyott jóvá az Európai Parlament.

A nyíregyházi Panelvizsgálat közvetlen hazai előzménye a TÁRKI által a kilencvenes évek elején elindított Magyar Háztartás Panel (MHP - később Háztartás Monitor, http3) országos kutatás. Ezen adatfelvétel lényegében az európai felmérésekkel azonos módszertani alapokra épülve mai is müködik. A kutatók kétévente vesznek mintát a magyar háztartások életkörülményeinek pontosabb megismerésére, a változások követésére.

Maga a nyíregyházi Háztartáspanel vizsgálat az előbb említett előzmények tapasztalataira építve indult meg 2008-ban. A módszertani hasonlóság lehetővé teszi a vizsgált területek nemzetközi összehasonlíthatóságát. A kutatás során alkalmazott kérdőívet minden vizsgálati hullám előtt Nyíregyháza Megyei Jogú Város Polgármesteri Hivatal Szociális Irodájának munkatársai, valamint a Debreceni Egyetemi Egészségügyi Kar kutatói felülvizsgálják, aktualizálják, frissítik. Ennek eredményeként például a kérdőív 2015-től új elemként tartalmazza az érzelmi jóllét dimenziót, mely az Oxford Boldogságmérö kérdéscsoport (Hills, Argyle, 2002) beillesztését jelenti a vizsgálatba - ez a bővítés teszi lehetővé kutatás során kidolgozott életminőség modell teljessé tételét (lásd jelen kiadványban - Takács, Fábián, 2018). Bővült a gazdasági aktivitást vizsgáló kérdésblokk is, továbbá bekerült az elmagányosodás vizsgálata a kérdések közé (http4). További előre lépés például az, hogy az egészségi állapottal foglalkozó kérdések a negyedik hullámban, 2015-től jobban illesztve voltak az Európai Lakossági Egészségfelméréshez (http5) is.

A véglegesített kérdőív tehát minden vizsgálati évben több nagy blokkra osztva vizsgálta a város lakóinak életkörülményeit. Ezek a blokkok a következők voltak:

1. Háztartások jellemzői (háztartás összetétele, lakhatás körülményei, problémák, háztartások felszereltsége, jövedelmi viszonyok).

2. Gazdasági aktivitás (munkavégzéssel kapcsolatos jellemzők).

3. Egészségi állapot (önmegítélés, megbetegedések és jellemzőik, alapellátás és szakellátás igénybe vétele, tartós betegségek).

4. Társas kapcsolatok (családi és emberi kapcsolatok jellemzői, kiterjedsége, intenzitása).

5. Időskorúak helyzete (a 65 éves, illetve annál idősebb lakosok életkörülményei). 
6. Támogató rendszerek - szociális kérdések és problémák (a természetes és mesterséges védőháló jellemzői, segélyezés, vélemények a segélyezési rendszerekről, a szociális ellátásról).

7. Szociális Osztály müködése (ügyfelek és véleményük).

8. Kulturális tőke - csak 2015-ben

9. Érzelmi jólét - Oxford Boldogságmérő Skála, 2015-től mérve

10. Biográfia (a megkérdezettek személyes jellemzői).

\section{A korábbi adatfelvételek jellemzése}

A 2008-2012 évi mintajellemzők. Az első minta címeinek kiválasztását - a kutatók által megadott peremfeltételek alapján - az MHP országos vizsgálattal egyezően - a Közigazgatási és Elektronikus Közszolgáltatások Központi Hivatala (http6) végezte. Véletlenszerúen lett meghatározva egy 2000 címet tartalmazó alapminta és egy 400 címet magába foglaló pótminta. Ez utóbbi a kieső, vagy a válaszadást nem vállaló címek pótlására szolgált. A mintába azok kerülhettek, akik 18. életévüket betöltötték és állandó lakcímmel rendelkező nyíregyházi lakosok voltak a lekérdezés idején. A kiválasztott minta reprezentativitásának ellenőrzése a nemi megoszlásra alapozva történt ezekben a hullámokban. Ennek indoka az, hogy a város lakosságára vonatkozó megbízható részletes adatok kizárólag a népszámlálásokból (2001) álltak rendelkezésre. Logikusnak tünt, hogy a több év viszonylatában inkább változó életkori és egyéb (például iskolázottság, életviteli- és munka-státuszok) adatok helyett a viszonylag állandó nemi megoszlás legyen az reprezentativitási alap. (5. táblázat)

Meg kell jegyezni, hogy a panelkutatások gyakorlatának megfelelően, a háztartásra vonatkozó válaszok súlyozatlanul kerültek felhasználásra, mivel ekkor a válaszadók személyes jellemzői nem tekinthetők relevánsnak. A válaszadó ilyenkor adatközlőnek (informátor) minősül; az elemzett, lekérdezett egység nem a személy, hanem maga a háztartás. A személyes adatokra vonatkozó elemzések viszont már súlyozottan jelenek meg az elemzésekben.

Az adatfelvételt minden vizsgálati hullámban - elözetes felkészítést követően - a Debreceni Egyetem Egészségügyi Kar képzéseinek hallgatói végezték. A megkeresés elött a címlista szereplői egy előzetes tájékoztató levelet kaptak a Polgármesteri Hivataltól, a polgármester/alpolgármester és a kutatásvezető aláírásával. Ebben a levélben a megkeresettek részletes tájékoztatást kaptak a vizsgálatról, annak céljairól és a várható megkeresési időpontról.

A 2015-2018 évek mintáinak sajátosságai. 2015-ben új címlistára volt szükség. A három adatfelvételi hullámot követően ezt a vizsgálatot is elérte a panelvizsgálatok nagy problémája, a „panelkopás” - okok: nagy lakóhelyi mobilizáció, magas válaszmegtagadási ráta. A címlista nagysága csökkent, 2015-ben 1000 háztartás került a föcímek közé, 500 a pótcímek listájára. A címeket ebben az esetben is a KEKKH (http6) szolgáltatta a korábbi paraméterek alapján (5. táblázat). 


\begin{tabular}{|l|c|c|c|c|c|}
\hline \multicolumn{1}{|c|}{ Év } & 2008 & 2010 & 2012 & 2015 & 2018 \\
\hline Minta nagysága & 2000 & 2000 & 2000 & 1000 & 1000 \\
\hline Elért háztartások száma & 1848 & 1060 & 1227 & 754 & 541 \\
\hline $\begin{array}{c}\text { Elért személyek száma } \\
\text { (becslés) }\end{array}$ & 4866 & 3066 & 2930 & $\begin{array}{c}\text { város: } 1899 \\
\text { járás: 2985 } \\
\text { összesen: 4884 }\end{array}$ & 1348 \\
\hline
\end{tabular}

5. táblázat. A kutatássorozat során elért háztartások, személyek 2008-2018. Megjegyzés: az adatok nem az elemzési mintanagyságot jelentik.

Adatfeldolgozás, elemzések. A mintavétel, az ellenőrzések és adattisztítások után kerültek a nyers adatok azokhoz a kutatókhoz (témagazdák), akik az egyes területek szükebb elemzéseit vállalták magukra. A 6. táblázat összefoglalja az öt hullám témafelelőseit, valamint azokat a kutatókat, akik ha nem is közvetlen módon, de érintve voltak más kutatásokkal az adatok feldolgozásában (részletesebben lásd (Fábián és mtsai., 2018).

\begin{tabular}{|l|l|}
\hline Téma & Témagazdák az egyes felmérési hullámokban \\
\hline Demográfia & 2008-2015 Malakucziné Póka Mária \\
\hline $\begin{array}{l}\text { Jövedelmi viszonyok, sze- } \\
\text { génység }\end{array}$ & $\begin{array}{l}\text { 2008-2015 Fábián Gergely, Takács Péter; 2012- } \\
\text { 2015 Szigeti Fruzsina }\end{array}$ \\
\hline Ėletminőség index & $\begin{array}{l}\text { 2008-2015 Takács Péter, Fábián Gergely, 2015 } \\
\text { Szigeti Fruzsina }\end{array}$ \\
\hline Lakáshelyzet, lakhatás & 2008-2015 Szoboszlai Katalin \\
\hline $\begin{array}{l}\text { Gazdasági aktivitás, munka- } \\
\text { nélküliség, nök helyzete }\end{array}$ & $\begin{array}{l}\text { 2018-2015 Rusinné Fedor Anita; 2012 Jávorné } \\
\text { Erdei Renáta; 2015 Balogh Erzsébet }\end{array}$ \\
\hline Egészségi állapot & $\begin{array}{l}\text { 2008-2012 Jávorné Erdei Renáta; 2008-2010 Jóna } \\
\text { György; 2012 Rusinné Fedor Anita, Berencsiné } \\
\text { Madácsi Eszter; 2015 Hüse Lajos }\end{array}$ \\
\hline Az idösek helyzete & 2008-2015 Patyán László \\
\hline Támogatórendszerek & $\begin{array}{l}\text { 2008-2012 Balogh Erzsébet; 2008-2010 Fábián } \\
\text { Gergely; 2012 Rusinné Fedor Anita; 2015 Krizsai } \\
\text { Anita, Tóthné Csatlós Ildikó }\end{array}$ \\
\hline Társas kapcsolatok vizsgálata & 2008-2015 Huszti Éva \\
\hline Anyagi depriváció & 2012-2015 Szilicsány Éva Panna \\
\hline Érzelmi jólét & $\begin{array}{l}\text { 2015 Szigeti Fruzsina, Fábián Gergely, Takács } \\
\text { Péter }\end{array}$ \\
\hline $\begin{array}{l}\text { A várost érintő és a Nyíregy- } \\
\text { háza Életminösége címú kuta- } \\
\text { tás közvetett körébe vonható } \\
\text { egyéb kari vizsgálatok }\end{array}$ & $\begin{array}{l}\text { 2012-2010 - Horváth László, Krizsai Anita } \\
\text { 2015 - Kovács Klára }\end{array}$ \\
\hline Szakértői munka, lektorálás & $\begin{array}{l}\text { Fónai Mihály } \\
\text { Kiss János }\end{array}$ \\
\hline & \\
\hline
\end{tabular}

6. táblázat. A nyíregyházi panelkutatás és kapcsolódó más

DE-EK kutatások témafelelősei 2008-2018. 


\section{Záró gondolatok - 10 év röviden}

Visszatekintve a fentebb leírtakra, feltehető a kérdés: Milyen eredményei és tanúságai is vannak a tíz év alatt lebonyolított öt kutatói felmérésnek?

A város számára talán a legfontosabb, hogy a felmérések révén egy-egy átfogó és megalapozott pillanatkép állt a döntéshozók, a vezetők rendelkezésére a nyíregyházi lakosok életkörülményeiről, életük/életünk számos vonásáról. Az elemzések a városi döntések részbeni megalapozói, alátámasztói voltak. A vizsgálati eredmények sok esetben fontos tényezőkre irányították rá a figyelmet.

Kiemelhető talán egyetlen eredmény - a többi éppen e kiadvány írásaiban olvasható. A nyíregyháziak összegzett, átlagolt válaszai igen sok esetben az országos átlagokat tükrözik. Kilépve azonban a városból - annak vonzáskörzetébe vagy még távolabbra, a megyébe, a régióba - rögtön érezhető az a lemaradás, amire az országos felmérések felhívják a figyelmet: Nyíregyháza „kiemelkedő szigetként” áll környezetében.

A Debreceni Egyetem Egészségügyi Karának kutatói és hallgatói számára a felmérések eredményes véghezvitele, az elemzésekből megszületett publikációk megjelenése elsődlegesen a kutatói tapasztalatot fejlesztette. A kezdetekkor a város viszonyainak megismerése jelentette a legfőbb hajtóerőt a kutatók számára. A célok elérése, az intézményi és személyes kapcsolatok épülése további értelmet ad a folytatáshoz. A kar bizonyította, hogy képes városi és járási szintü vizsgálatok tervezésére és lebonyolítására. A kutatók reményei szerint ezek a hosszabb távú trendeket is feltáró kutatások hozzájárulnak Nyíregyháza további fejlődéséhez.

\section{Irodalomjegyzék}

1. A Nyíregyházi járás életminősége 2015. Szerk.: Hüse L., Takács P., Huszti É.. Acta Medicinae et Sociologica Vol. 6. No. 18-19. 2015.

2. Chew L.D., Griffin J.M., Partin M.R., Noorbaloochi S., Grill J.P., Snyder A., (2008): Validation of Screening Questions for Limited Health Literacy in a Large VA Outpatient Population, J Gen Intern Med. 23(5): 561-566.

3. Életminőség Nyíregyházán 2008-2010. Szerk.: Fábián G., Patyán L., Huszti É.. Acta Medicinae et Sociologica Vol. 3. No. 3. 2012.

4. Életminőség Nyíregyházán 2012. Szerk.: Huszti É., Patyán L., Fábián G.. Acta Medicinae et Sociologica Vol. 5. No. 12-13. 2014.

5. Fábián G., Huszti É., Hüse L., Takács P. (2018): Az életminőség Nyíregyházán - A nagymintás társadalomkutatás első négy hulláma a megyeszékhelyen. Szabolcs-Szatmár-Beregi Szemle, 2018/3 p. 83-102.

6. Hills, P., Argyle, M. (2002): The Oxford HappinessQuestionnaire: a compactscaleforthemeasurement of psychologicalwell-being, InPersonality and IndividualDifferences, Volume 33, Issue 7., 1073-1082, https://doi.org/10.1016/S0191-8869(01)00213-6 (2018.11.29.)

7. Jávorné Erdei R. (2016): Nyíregyháza város lakosságának életminősége az egészségi állapot tükrében. Doktori disszertáció, Pécsi Tudományegyetem 
Egészségtudományi Kar, Egészségtudományi Doktori Iskola, Pécs. Elérhető: http://tsp.etk.pte.hu/portal/wp/File/Doktoriiskola/Tezisfuzetek

/Javorne_Erdei_Renata_dissz.pdf; 2016 (2018.10.09.)

8. Jávorné Ërdei R, Takács P, (2018): Szubjektív egészségi állapot és annak változásai Nyíregyházán. Acta Medicinae et Sociologica Vol 9., No.27. 96-109

9. Koltai J., Kun E. (2016): The practical measurement of health literacy in Hungary and international comparision. Orvosi Hetilap, 157(50), 2002-2006. Elérhető: https://akademiai.com/doi/pdf /10.1556/650.2016.30563 (2018.12.01.)

10. Papp-Zipernovszky O., Náfrádi L., Schulz P.J., Csabai M., (2016): "So that each patient may comprehend": measuring health literacy in Hungary. Orvosi Hetilap;157(23):905-15.

11. Szelényi B. (2003): Az adatbázis súlyozása. In Kapitány Balázs (szerk.): Módszertan és dokumentáció. Az adatfelvétel ismertetése. Műhelytanulmányok 2. KSH Népességtudományi Kutatóintézet, Budapest, 51-63.

12. Takács P., Fábián G. (2018): Lokális Életminőség Index, Nyíregyháza 2018 valamint a multihalmaz alapú vizsgálatok lehetőségei. Acta Medicinae et Sociologica Vol. 9. No. 27., 70-95.

13. Weiss B.D., Mays M.Z., Martz W., Castro K.M., DeWalt D.A., Pignone M.P., (2005): Quick Assessment of Literacy in Primary Care: The Newest Vital Sign. The Annals of Family Medicine, 3. 6. sz. 514-522.

\section{http}

1. http1 - Az 'European Community Household Panel' (ECHP) kutatás weboldala. Elérhető: https://ec.europa.eu/eurostat/web/microdata/european-communityhousehold-panel (2018.12.01.)

2. http2 - Az 'European Union Statistics on Income and Living Conditions' (EUSILC) weboldala. Elérhető: https://ec.europa.eu/ eurostat/web/microdata/ european-union-statistics-on-income-and-living-conditions (2018.12.01.)

3. http3 - A TÁRKI Magyar Háztartás Panel kutatás weboldala. Elérhetö: https://www.tarki.hu/magyar-haztartas-panel (2018.12.01.)

4. http4 - Manual of the Loneliness Scale 1999, Vrije Universiteit Amsterdam. Elérhető:

http://home.fsw.vu.nl/tg.van.tilburg/manual_loneliness_scale_1999.html (2018.12.01.)

5. http5 - Európai Lakossági EgészségFelmérés (ELEF) magyar weblapja. Elérhetö: http://www.ksh.hu/elef (2018.12.01.)

6. http6 - A Belügyminisztérium Nyilvántartások Vezetéséért Felelős Helyettes Államtitkárságának honlapja, KEKKH. Elérhető: http://nyilvantarto.hu/hu/ (2018.12.01.) 